\title{
The Right to Elementary Education in India: Connotations and Reflections
}

\author{
Manu Singh", ${ }^{1, *}$ Shivendra Shivam Singh Rathore ${ }^{2}$ \\ ${ }^{1}$ Gitarattan International Business School, New Delhi, India \\ ${ }^{2}$ Amity Law School, Amity University Lucknow Campus (UP), India
}

Received June 5, 2020; Revised July 24, 2020; Accepted August 10, 2020

\begin{abstract}
Cite This Paper in the following Citation Styles
(a): [1] Manu Singh, Shivendra Shivam Singh Rathore, "The Right to Elementary Education in India: Connotations and Reflections," Universal Journal of Educational Research, Vol. 8, No. 9, pp. 4173-4178, 2020. DOI: 10.13189/ujer.2020.080943.
\end{abstract}

(b): Manu Singh, Shivendra Shivam Singh Rathore (2020). The Right to Elementary Education in India: Connotations and Reflections. Universal Journal of Educational Research, 8(9), 4173-4178. DOI: 10.13189/ujer.2020.080943.

Copyright $\odot 2020$ by authors, all rights reserved. Authors agree that this article remains permanently open access under the terms of the Creative Commons Attribution License 4.0 International License

\begin{abstract}
This Research paper deals with the conditions of the education of children in India, the various schemes and policies carried out in providing education. How Elementary Education has developed in India? Attempts are made to find out the laws in the country, in which basic education finds the place in this respect nature and scope of Right to Education Act has been analysed. Education plans, policies and various Government schemes have been discussed. Paper examines and investigates the constitutional growth of Education with aims to achieve the goal of equal opportunity to all and social justice as enshrined in the Preamble of the Constitution. Various articles inherent in the Indian constitution have been discussed. Judicial response to the need of the right to education has also been highlighted. Global Commitment for Compulsory Education has also been discussed with agenda 2030 which refers to the global dedication of the Education for all. Lastly, there is a conclusion and some suggestions. The certainty and promise RTE Act which shows up on paper should be fulfilled in its execution which is very defective. Despite the fact that several legislative enactments, judicial pronouncements, and many government schemes make effective implementation of elementary education, we are lacking behind to achieve the desired goals and to meet with an international commitment regarding compulsory education. In the same way, as other endeavoured social changes in India, this also needs to begin at the grass-root level and requires a boundless effort to make a difference in a deep-rooted mind.
\end{abstract}

Keywords Elementary Education, Government Plans, Fundamental Rights, Compulsory Education Act, 2009

\section{Hypothesis}

The Right of Children to free and compulsory Education Act 2009 neglects to give educational facilities to all kids underneath the age of 6 years as given in article 45 of the Indian Constitution. Also, it doesn't consider the necessities of children beyond $14-18$ years old.

\section{Purpose of the Study:}

i) To examine the constitutional development of Education. Interlaced with intends to accomplish the objective of the equivalent chance to all mentioned in the Preamble of the Constitution.

ii) To analyse deficiency in the Act and make a basic evaluation of obstacle, over a significant time span, and different constraints lying in the pathway of the Act by considering disregarded realities and the manners by which the information is denied to the individuals and study the demeanor of governing bodies.

\section{Methodology}

The research study basically follows the doctrinal 
method technique in the gathering, comprehension and systematization of the basic and optional sources material.

The study is doctrinal and didn't rely upon expansive field reviews. Fundamental sources like Indian Statues, rules and rules report of the working committees, standing committees, and Cabinet Committees are the reason for study. Reports conveyed by non-administrative affiliations (NGOs) and self-overseeing lawful bodies have furthermore been discussed.

\section{Table of Content}

1. Introduction

2. Indian Education during Ancient Period

3. Constitution Development of Compulsory Education

4. Government Plans and Strategies on School Education

5. Judicial Activism and Compulsory Education

6. Elementary Education: An International Perspective

7. Right to Education Act 2009: An Critical Appraisal

8. Global Commitment for Compulsory Education

9. Conclusion

10. Suggestions

11. References

\section{Introduction}

There are several meanings of Education, which come closest to its score and is that education is the thing that residual parts with you after you have lost all that you perceived at school, college, or university. Education breaks all preventions and strengthens all bonds. It is the preparation of the mind, not the stuffing of the brain. It is the absorption of thoughts, not the dissemination of information. It has continued developing assorted variety and grown its range since the start of humanity's history.

Education is extensively observed, as a pivotal vehicle for social and economic development. The strong linkages between the countries, positive externalities related with expansion of education, wide knowledge of its public great character, and the particular historical context of the developing countries have made open strategy towards education, one of the most basic areas of administration in current time.

In addition, it is perceived that public expenditure on education maybe the most critical piece of such a system. Private choice frequently dismisses the positive externalities related with improved education and there are not kidding 'showcase disappointment' in the private provisioning for education. Also from the perspective of value and rights, there can be little vulnerability about the way that private provisioning through the market instrument is regularly mediocre. Public expenditure on education anticipates a great significance, especially in a country like India, which has around $33 \%$ of without a doubt the number of uneducated people on the planet.
India's underachievement in school instruction may basically be striking, specifically given our accomplishment in numerous fields of advanced education and particular training, however, the direness of school education is certifiably not a particular characteristic of our nation. The mission was seen, in the mid-nineteenth century, with eminent meaningfulness in Japan, the principal nation to coordinate with the West. The Fundamental Code of Education, given in 1872. [1] (Shortly after the Meiji Restoration in 1868), communicated the open pledge to ensure that there must be "no people with an ignorant family, nor a family with an illiterate individual". Kido Takayoshi, one of the pioneers of Japanese change, clarified the fundamental thought: "Our kin are the same as the Americans or Europeans of today; it is every one of the matters of education or absence of education." [2]

Thus Japan's surprising efforts at matching up with West are started. By 1910, Japan was completely educated, and by 1913 , however, still especially more unfortunate than Britain or America, Japan was publishing a greater number of books than Britain and more than twice the same number of as the United States. [3] Later on, China, Taiwan, South Korea and different economies in East Asia followed comparable courses and solidly centered on fundamental education. In clarifying their fast advancement, their eagerness to utilize the worldwide market economy is regularly applauded, and as it should be. In any case, that procedure was incredibly helped by the accomplishments of these nations in fundamental training. Despite the fact that popular government can bring significant advantages even without all inclusive proficiency, an informed population can utilize equitable chances. Female proficiency can upgrade women's voice in family issues and diminish sex imbalance in different fields too. Since women's strengthening through proficiency will in general diminish child mortality and altogether decline fertility rates. [4] Relevance with fertility is not direct yet in any way astonishing. To get this, we need to hold up under as a main priority that the carries on with that are generally troubled and ruined by over regular bearing and raising of kids are those of young ladies. A more noteworthy voice of young ladies in family choices tends to reduce birth rates.

Removing illiteracy and poverty was also the main concern for which India had battled. Those objectives have remained under accomplished, and even the general pace of total financial advancement was modest. Notwithstanding, India has, in any event, pointedly improved its total development pace of GDP, by and large through the financial changes which were first started by Manmohan Singh as a Finance Minister in the early 1990s.[5] However, the gradualness of progress on school education has been taking a very long time and efforts to cure.

The committee of the Indian Constitution made an intense stride in giving the option to cast a ballot to each 
resident who isn't under 21 years old when more than $66 \%$ of the population was poor and illiterate. Constituent Assembly Debates, Vol.XI, p.989.) After due pondering, Alladi Krishnaswamy Aiyar, from the drafting council, in his Srinivasa Sastri Memorial Lecture, enunciated the explanations behind embracing all inclusive grown-up establishment foundation in the Constitution. He said, if democracy-based system government is to be wide-based and the arrangement of government that is to work is to have a complete assent of the individuals as a rule, in a nation where a mass of people are uneducated, where the people having property are relatively few, and the presentation of any property or instructive capabilities for the activity of the establishment would be a nullification of the norms of standards of democracy system.

Nani Palkhivala in his book "We, the Nation, the Lost Decades" [6] explains that Education is the stone on which India should construct political salvation. Our nation will be assembled now not on blocks anyway on minds; presently not on concrete however on illumination. In the event that we can't have the assets for education, we can't discover the money to stay as a humanized society. It is expressed everywhere throughout the world that expense primarily based education is the exclusive instrument for transmuting countrywide mind into national advancement. Among the vital countries of the world, India isn't viably educated. Article forty-five of our constitution orders: The State will try to give, until the age of ten years from the beginning of this Constitution, for free education for all children until they obtain the age of fourteen years. He concluded that Education is an end of itself; and now not in basic terms a necessary chore like money related prosperity. There ought to be no profit reason in liberal education.

At that point, knowledge alone would be able to ripen into insight. Thus Palkhivala comments that the education framework in India isn't good and does now not make intellectually sound elites. A wide assortment of examples has preceded the court where the last has communicated its requirement for free and compulsory education for kids in India.

This is the reason the Universal Declaration of Human Rights Act, 1948 underlines "education will be coordinated to the full advancement of the human character. [7] Article forty-one in chapter IV of the Constitution of India perceives a person's right "to education".

The nation will inside the restrictions of its financial ability and improvement, make pleasant arrangement for tying down the privilege to education." Education is a procedure of human turn of events or more all strengthening for the satisfaction of a higher and more prominent personal satisfaction.

\section{Indian Education during Ancient Period}

An informed and educated society readies the current generation for a bright future and empowers the individual, which helps to build the nation. "Guru" was the pivot of the educational system. They imparted education orally to his pupils individually and privately in their homes or "ashramas."

The teachers were called by the titles of "Acharya" and "Upadhyaya" and pupils were called "Sishyas" or "Brahmacharis". "Bhattas" was the special title assumed by the learned "Brahman" teachers.

The study of the four 'Vedas', six 'Vedangas', the 'Puranas', 'Smritis', 'Mimamsa', Nyaya, 'Dharma' or Law, Logic, Philosophy, Prakrit literature, Mathematics, Metaphysics, Sanskrit-Grammar, Medicine, and Astronomy-cum-Astrology, etc. were the main subjects of study. Secular subjects were also taught.

Among the famous centers of education, Taxila was on the decline. Nalanda was rising to its fame as a university under the rich patronisation of the Gupta rulers. Other important Buddhist monasteries began to develop as centers of education or monastic colleges during the latter half of the Gupta period.

Among the other centers of education were Pataliputra, Vallabhi, Ujjaini, Padmavati, Basin, Pravarapura, Mathura, Ayodhya, Varanasi, Nasik and Kanchi and Agrahara. Villages had also become famous centers of higher education and learning. In South India, centers of higher education were called "Ghatikas" and probably located in temples.

Thus, Gupta age witnessed progress in science and education or rather in every field of knowledge. It was an age of intellectualism which led to progress and new inventions and innovations in every field of learning.

Chanakya had clarified "that mother and that father are adversaries, who don't facilitate education to their children

History is full of instances of caste, class and sex-based discrimination in providing education. Education turned into the main benefit of the sanctified class (Brahmins) essentially by virtue of the strict establishment for the substance of tutoring, mixed with the elitist method of guiding that got to bestow training. Admission to Gurukulas or Ashramas transformed into now not open to all. Individuals from the lower caste, subsequently called 'shudras'(untouchables), explicitly, have been prohibited from getting schooling. Few of insightful Brahmins began Pathasalas (schools) in gigantic urban areas in which they got support.

\section{Constitutional Development of Compulsory Education}

Education has become the obligation of the states. The Central Government's just obligation went into to co-ordinate in specialized and better schooling and specifies standard. This proceeded until 1976, while the instruction turned into a joint duty of the nation and the Centre. Education in India falls beneath the control of each of the Union Government and the states, with a couple of duties deception with the Union and the states having self-governance for other people. The various articles of the Indian Constitution accommodate education as a basic 
right. Most colleges in India are controlled by the Union or the State Government. India has made advancement concerning expanding the number of schooling participation rate and extending the education rate to roughly two-third of the population.

Article 38 of the Indian Constitution focuses on the state to make sure about a social request for the advancement of government assistance of the individuals. Article 39 gives that the State will, specifically, direct its strategy towards making sure about given opportunity and facilities to develop a healthy manner and condition of freedom and dignity.

Article 41 cherished in Part IV of the constitution plans to give the opportunity to work, to education, and to open help with specific cases.

Article 45 aims at accommodating youth care and education to kids underneath the age of six years.

Article 46 focuses on the advancement of instructive and monetary interests of Scheduled Castes, Scheduled Tribes, and other weaker segments.

Article 21A provides free and compulsory education.

Article 51A (k) the 86th amendment further added as an important obligation on part of a "parent to give facility for education to all children from the age of 6 to 14 years.

\section{Judicial Activism and Compulsory Education}

Legal understanding has brought alive numerous an article of the Constitution, which whenever read actually may appear to be a colourless article of importance to education, for example, is the wide interpretation given to the words 'individual; freedom'.

By Justice Bhagwati in Francis Coralie Mulin v Administrator, Union Territory of Delhi 1981, 746.also threw light on the importance of education.

The Supreme Court in its judgment in Bandhua Mukti Morcha v, Union of India, 1997 (5) SC 285, cited the importance of human dignity.

In Maharashtra State Board of Secondary and Higher Education v. K.S. Gandhi JT, 1991(2) SC 296 it has been held in this case that the right to education is a fundamental right of every citizen.

In J.P.Unnikrishnan V. Province of Andhra Pradesh, 1993(1) SC 474. A constitution Bench had held education up to the age of 14 years to be basic and important.

In Mohini Jain v. State of Karnataka AIR, 1992 SC 1858 it was concluded that Thus court ruled that the right to education comes directly from article 21 and state is under the constitutional mandate to provide education at all institutional for the benefit of citizens.

Unni Krishnan v. State of A.P.AIR 1993(1) SCC 645, 732 also cited the importance of education.

\section{Government Plans and Strategies for School Education}

Education assumes the most significant role for social, political changes. An accomplished populace, prepared with the relevant information, mentalities, and abilities, is significant for monetary and social advancement in the twenty-first century. Education additionally goes about as an integrative power in the public eye, giving qualities that encourage social solidarity and national identity. India, Planning Commission, Draft Twelfth Five Year Plan (2012-2017) Volume-III, p. 48. [8]

So as to acquire the Universalisation of Elementary Education, the Government of India has begun some projects and undertakings. The Government embraces coordinated strategies in the usage of the various midway financed plans, which comprises with the thought of the National Policy on Education, to verify that the education of impartial quality for all totally saddle the Nation's human asset potential. The common goals are to improve access through the extension of extraordinary school education; to advance value through the consideration of hindered gatherings and a more vulnerable section, and to improve the quality of education.

\section{i) Kothari Commission (1964)}

ii) The National Policy on Education, 1968

iii) The National Policy for Children, 1974

iv) National Policy on Education, 1986

v) Sarva Shiksha Abhiyan

vi) Kasturba Gandhi Balika Vidyalaya

vii) National Program for Education of Girls at Elementary Level

viii) Mid-Day Meal Scheme

\section{ix) The Rashtriya Madhyamik Shiksha Abhiyan}

Notwithstanding of all these above different referenced government plans and arrangements, we can't overlook the most concerning issue which comes in the way of accomplishing the plan of giving the essential education to all, and that is the dropout rates among the students however in the present time we have accomplished full enrolment among students yet we can't disregard the darker side of dropout rates from school among the students, to have a superior task of the significant difficulties and reasons for the dropouts we can have a look at the below referenced reasons likewise economic reasons as well as academic reasons.

\section{Elementary Education: An International Perspective}

India is a signatory member several international organisations that ensure the privilege to basic education Universal Declaration of Human Rights, 1948, the International Covenant on Economic, Social and Cultural Rights, 1966 and the Convention on the Rights of the Child, 1989 Historically, and there has been an urge for free and 
obligatory education (FCE) in India as well.

\section{Right to Education Act 2009: An Critical Appraisal}

In 2002, through the 86th Amendment Act, Article 21(A), it was incorporated in the constitution of India. It made the privilege to basic education some portion of the privilege to opportunity, expressing that the State would give free and mandatory education to kids from six to fourteen years old. Six years after a revision was made in the Indian Constitution, the association cleared the Right to Education Bill in 2008 The Right of Children to Free and Compulsory Education Act or Right to Education Act (RTE), which was passed by the Indian Parliament in 2009.

Despite the fact that several legislative enactments, judicial pronouncements, and many government schemes make effective implementation of elementary education, we are lacking behind to achieve the desired goals and to meet with an international commitment regarding compulsory education.

\section{Global Commitment for Compulsory Education}

This agenda 2030 refers to the global dedication of the Education for All development to ensure access to fundamental education for all, the basic part of the 2030 Agenda for Sustainable Development. The roadmap of Agenda is the Education 2030 Incheon Declaration and Framework for Action, which outlines how nations, working with UNESCO and overall accomplices, can make an interpretation of commitments into action.

While the rule obligation for forcing the plan lies with governments, UNESCO and accomplices offer help with interrelated arrangement exhortation, specialized help, and capacity improvement at global, provincial, and national levels.

\section{Conclusions}

The child is a soul with a being, a nature and capacities of its own, who must be helped to find them, to grow into their maturity, into a fullness of physical and vital energy and the utmost breadth, depth and height of its emotional, intellectual and spiritual being; otherwise there cannot be a healthy growth of the nation."

\section{- Justice PN Bhagwati}

In India where millions of children are living on streets, where millions of children are bonded labour due to poverty, many girls don't reach their puberty age only 50 percent of children have access to education. India has the biggest number of adolescents, particularly compared to nations like China, which has a huge crowd of old age people. But it is very unfortunate to state that, India has $33 \%$ of the world's uneducated population. It's not like proficiency levels have not expanded, but instead that the pace of the expansion is quickly going back. To battle this troubling pattern, the Indian government came with the RTE Act making education an important right of each youngster between the age of 6 to 14 years.

Presently, it is to be seen, as how far this basic law would be effective enough to cover the huge number of kids in our nation, who are essentially the survivors of bonded work and neediness. Enactment alone won't remove this disregard. Coordinated efforts, by each person, are requested to accomplish the ideal, so it doesn't bring about the law just on paper. It's the education that can make our nation sparkle at the worldwide and can help in building a nation.

UNICEF expressed that the condition of education in India has not improved much since 2009, since then the RTE was first proposed.

To anticipate that, laws should be changed. There has been extensive advancement in the education system in the recent decade because of endeavours like SSA and RTE. The student educator proportions have fallen more than 20 percent (from 47.4 to 39.8), portions of schools with latrines and power have dramatically increased, and so on. These are all accomplishments of the state framework.

The RTE Act doesn't do what's necessary to empower peripheral enhancements in quality and encourage innovative arrangements inside the bigger framework.

It is by all accounts an unassailable certainty that the RTE Act shows up, on paper, to be a perfect answer for the issues relating to education in India, but its execution has been very defective. Despite the fact that state education offices and training specialists are answerable for checking the usage of the Act, this obligation doesn't appear to have been paid attention to. There are no extraordinary review components like on account of NREGA. This responsible system is powerless practically in all states and legal activism through PILs has been normal and there is no sensibly effective plan of action.

\section{Suggestions}

i) In India, it should be compulsion for free and mandatory basic education, first to eighth grade. This implies that it should be mandatory in every school to follow basic measures for elementary education.

ii) It should be monitored that Parents of youngsters secured under RTE are not at risk to pay for school expenses, course readings, noontime meal, transportation, until the basic training is finished.

iii) If a youngster has not figured out how to make sure about admission in a school as per age, it should be the government's obligation to get the kid enrolled during a time in a suitable class.

iv) Schools should sort out instructional courses to permit such a youngster to find other courses.

v) No kid will be kept down or removed until the completion of elementary education. 
vi) Not obeying the RTE rules can face a punishment of Rs 25000, punishment related provisions should make more effective and strict.

vii) There is "no disappointment" strategy that the Act endeavours to actualize, all efforts taken by the government should be analysed every year.

viii) Studies should be tried through various configurations, for example, introductions, ventures, open exhibitions and so forth, However, in light of the fact that CCE isn't seen appropriately by authorities in numerous schools, kids are continually passed to higher evaluation levels, whether or not they are set up for that more significant level of work.

ix) Most schools use CCE as a medium to pardon themselves from seeking after thorough work with their kids. Most kids coast through the framework without accomplishing any huge learning results. Further, kids from helpless families are regularly pulled out of school by their families, who need them to work. State and National kid rights commissions have been working effectively with governments to decrease the level of kids out of school and in youngster work. Actually, there is as yet far to go to accomplish 100 percent enlistment and guarantee maintenance inside a school for at any rate 8 years of education.

x) There should be provisions in the Act to execute a Comprehensive Curriculum Evaluation (CCE), to guarantee that tests are not the particular proportion of a youngster's advancement during a scholastic year.

xi) Passing an authorization is as simple assignment yet the key in guaranteeing this Act is effective, is to make guardians, in every part the of country, In the same way as other endeavoured social changes in India, this also needs to begin at the grass-root level and requires a boundless effort to make a difference in a deep-rooted mind.

\section{REFERENCES}

[1] Yamamura S. National Education Policy and the Masses in Modern Japan: The Origins of a State-Oriented Mentality and the Long Detour to a New Form of Citizenship Education. JAPANESE EDUCATION IN TRANSITION 2001: Radical Perspectives on Cultural and Political. 2002 Oct;3(5):5.
[2] Brown SD. Kido Takayoshi (1833-1877): Meiji Japan's Cautious Revolutionary. Pacific Historical Review. 1956 May 1;25(2):151-62.

[3] Larson EL. United Nations Fourth World Conference on Women: Action for Equality, Development, and Peace (Beijing, China: September 1995). Emory Int'l L. Rev.. 1996;10:695.

[4] Tharoor S. India: From midnight to the millennium. Penguin Books India; 2000.

[5] Crockett DA. The opposition presidency: Leadership and the constraints of history. Texas A\&M University Press; 2002.

[6] Palkhivala Nani A. We, the nation-The lost decades.

[7] Assembly UG. Universal declaration of human rights. UN General Assembly. 1948 Dec 10;302(2).

[8] SyamRoy B. Family Welfare Approaches in the Five Year Plans. In India's Journey towards Sustainable Population 2017 (pp. 273-295). Springer, Cham.

\section{Books referred}

[9] Ruhela SP. India's Struggle to Universalize Elementary Education. MD Publications Pvt. Ltd.; 1996.

[10] Dash M. Education in India: Problems and perspectives. Atlantic Publishers \& Dist; 2004.

[11] Nair DS. Human rights vis-a-vis right to education in Indian context: problems and issues.

\section{Other Sources [Web Links]}

[12] http://www.legalserviceindia.com/article/1407.html

[13] http://www.unesco.org.html

[14] https://www.indiakanoon.org/doc.html

[15] http://www.jstor.org/stable/3635293.html

[16] http://parliamentofindia.nic.in/ls/debates/vol11p3.html

[17] http://www.ncpcr.gov.in/Acts.html

[18] http://parliamentofindia.nic.in/ls/debates/vol7p2a.html

[19] https://www.unhcr.org/refworld/docid/3ae6 b38f0.html

[20] http://www.unhcr.org/refworld/docid/3ae6b3970.html

[21] http://indiabudget.nic.in/es2005-06/chapt2006/chap106.pfd. html

[22] http://www.ncert.nic.in/html/pdf/FinalNCERT.pdf.html 